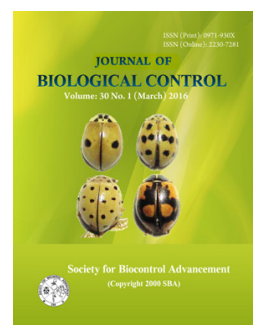

\title{
Efficacy of lignophenolic composts for the management of bacterial wilt of tomato
}

\author{
C. F. GLEENA MARY* and SALLY K. MATHEW \\ Department of Plant Pathology, College of Horticulture, Kerala Agricultural University, Vellanikkara, Thrissur - 680656, Kerala, India. \\ *Corresponding author E-mail: gleenashaj@gmail.com
}

\begin{abstract}
Bacterial wilt is one of the most dreaded diseases in tomato growing areas all over the world. Though chemical control measures and resistance breeding offers certain degree of protection against wilt pathogen, both have their own limitations such as high cost, environmental impact, non target effect and development of resistance. Hence, biologically safe methods such as use of composts as soil amendments for wilt management was investigated in the present study which revealed the possibility of the use of ligno-phenolic composts in disease management. Among the five composts tested, application of ayurvedic compost at 45 days after planting was found to be the most effective with lowest wilt incidence of 6.94 per cent against 36.10 per cent in control, with 80.77 per cent disease reduction. At 60 DAP, same trend was noticed with minimum disease incidence in ayurvedic compost (13.88 \%) which was on par with full basal application of leaf litter compost (15.27\%), and coir pith compost (16.66\%) with 86.79 to 60.02 per cent reduction of wilt incidence. In case of yield, among the different composts, split and basal application of ayurvedic compost recorded highest yield of $8.9 \mathrm{~kg} / 6.48 \mathrm{~m}{ }^{2}$.
\end{abstract}

KEY WORDS: Ayurvedic compost, bacterial wilt, coir pith compost, leaf litter compost, tomato

(Article chronicle: Received: 14-11-2015; Revised: 14-02-2016 ; Accepted: 06-03-2016)

\section{INTRODUCTION}

The bacterial wilt disease incited by Ralstonia solanacearum (Smith) Yabuuchi et al., 1995 is one of the most ubiquitous and damaging bacterial disease in tropical and subtropical countries (Kelman, 1953; Hayward, 1991). It is widespread throughout India and a yield loss upto 100 per cent was reported (Sadhankumar, 1995). The versatility and soil borne nature of the pathogen makes the chemical disease control difficult and costly. Location specific biocontrol measures for disease control are probably the cheapest strategies available and the most satisfactory from an ecological point of view.

Kerala being the land of coconut and ayurveda, generates sizeable amount of agrowastes as by products from coir and ayurvedic medicine manufacturing units. Moreover, the plantations of cashew and teak also add to the agrowastes with less degradability. These agrowastes rich in cellulose, lignin, phenols /tannins are normally resistant to biodegradation and takes longer period for degradation. Even though these chemicals lower the degradability of agrowastes, they are found to be inhibitory to several pathogenic microorganisms. Hence in this study we explored the disease management potential of the composts from lignophenolic agrowastes against bacterial wilt of tomato.

\section{MATERIALS AND METHODS}

\section{Preparation of ligno-phenolic composts}

Microbial degraders with the ability to degrade cellulose, lignin and tannin/phenols were isolated on their respective selective media. Cellulose degraders were isolated on Dubo's medium for cellulose degraders (Deokar and Sawant, 2004), lignin degraders on lignin sulphonate medium (Thimmaiah, 1989) and tannin degraders on tannic acid medium (Thormaan et al., 2002). The most efficient degraders were selected based on in vitro studies on media as well on their host substrates. They were further evaluated in vivo on host as well as other lignin-tannin rich substrates and a microbial consortium was developed with 10 most efficient, mutually compatible degraders. This consortium was evaluated for its efficacy in reducing the composting period of lignin-tannin/phenol rich substrates viz. ayurvedic waste, coir pith, leaf litters of cashew, teak and mango and also on the mixture of all these substrates in a field level aerobic composting experiment. These composted agrowastes were evaluated for their potential for the management of bacterial wilt in this study.

\section{Field evaluation of ligno-phenolic composts}

A field experiment was conducted in the research plot to study the efficacy of ligno-phenolic composts in the 
management of bacterial wilt of tomato caused by $R$. solanacearum. The study was conducted during Oct. 2013 - Jan. 2014 in the wilt sick plots. Composts and cow dung were applied@ 25 t/ha as full basal and in two splits. NPK fertilizers and chemical fungicide were also included for comparison. The details of the experiment are as follows. The experiment was laid out with variety Mukthi in Randomised Block Design with a plot size of $2.7 \times 2.4 \mathrm{~m}$. Twenty four plants were planted in each plot and replicated thrice.

\section{Treatments details}

T1- Ayurvedic compost - full basal

T2- Ayurvedic compost $-1 / 2$ basal $+1 / 2$ top dressing, 30 days after planting (DAP)

T3- Coir pith compost - full basal

T4- Coir pith compost $-1 / 2$ basal $+1 / 230$ DAP

T5- Leaf litter compost - full basal

T6- Leaf litter compost - $1 / 2$ basal + $1 / 230$ DAP

T7- Mixture compost- full basal

T8- Mixture compost $-1 / 2$ basal $+1 / 230$ DAP

T9- Ordinary compost - full basal

T10- Ordinary compost $-1 / 2$ basal $+1 / 230$ DAP

T11- Cow dung@25 t/ha - full basal

T12- Cow dung $-1 / 2$ basal $+1 / 230$ DAP

T13- Copper hydroxide - 2g/1 - ATP + 30 DAP

T14- NPK fertilizers as per POP @ 75:40:25 kg/ha - 1/2 basal $+1 / 230$ DAP

T15- Control (with out treatment)

\section{Preparation of field and transplanting}

Experimental plots were prepared by ploughing followed by levelling. Shallow trenches were taken at a length of $2.7 \mathrm{~m}$ and width of $30 \mathrm{~cm}$ and NPK fertilizers were applied as urea, rajphos and muriate of potash @ 163, 200 and $42 \mathrm{~kg} / \mathrm{ha}$. Soil drenching of copper hydroxide $(2 \mathrm{~g} / \mathrm{l})$ was given at the time of planting and 30 days after planting. Thirty day old seedlings were planted at a spacing of $45 \mathrm{~cm}$ between plants and $60 \mathrm{~cm}$ between the rows with 24 plants in each plot. Observations were recorded on wilt incidence at 30,45, and 60 days after transplanting, plant height, days to flowering and fruiting, number of fruits/plant, yield/plant as well as yield/plot and statistically analysed with statistical package, MSTAT (Freed, 1986). Multiple comparisons among the treatments were done using Duncan's multiple range test (DMRT).

\section{RESULTS AND DISCUSSION}

Bioefficacy of various lignin-tannin rich compost products were evaluated against bacterial wilt of tomato caused by $R$. solanacearum. Observations on wilt incidence and biometric characters were recorded at 30, 45 and 60 days after planting (DAP) (Tables 1, 2 and 3). Per cent wilt incidence at 30 DAP showed no significant difference among the treatments (Table 1). However, all treatments were superior to control at 45 and 60 DAP with minimum incidence of 4.16 per cent and 6.93 per cent in check plot - T13 (soil drenching with copper hydroxide, 2g/l). Among the other treatments, lowest incidence was observed in split application of ayurvedic compost - T2 with 6.94 per cent against 36.10 per cent in control, recording 80.77 per cent disease reduction.

At 60 DAP, same trend was noticed with minimum disease incidence in T2, split application of ayurvedic compost $(13.88 \%)$ which was on par with full basal application of leaf litter compost - T5 (15.27\%), ayurvedic compost -T1 (16.66 \%) and coir pith compost -T3 (16.66 \%) against 41.68 per cent in control and these treatments showed 86.79 to 60.02 per cent reduction of wilt incidence.

In the biometric characters (Table 2), significant difference was noticed only with respect to plant height and among the treatments, application of chemical fertilizers $\mathrm{T}_{14}$ recorded maximum plant height $(59.96 \mathrm{~cm})$ followed by the application of NPK with copper hydroxide $\left(T_{13}\right)$ which were on par with basal application of cow dung and split application of ayurvedic compost $\left(\mathrm{T}_{11}\right.$ and $\left.\mathrm{T}_{2}\right)$. No significant difference was noticed with respect to days to flowering and to first harvest.

With respect to yield parameters, significant difference was noticed with respect to number of fruits per plant, weight of fruits, yield per plant and yield per plot, which varied with the treatments. From the data showed in Table 3, it is found that, among the treatments, NPK application $\left(\mathrm{T}_{14}\right)$ showed maximum number of fruits per plant (20.82) whereas, split application of ayurvedic compost $\left(\mathrm{T}_{2}\right)$ recorded maximum weight of the fruit $(40.36 \mathrm{~g})$. Yield per plant $(799.24 \mathrm{~g})$ and yield per plot $\left(12.4 \mathrm{~kg} / 6.48 \mathrm{~m}^{2}\right)$ 
Table 1. Efficacy of various composts on the management of bacterial wilt of tomato

\begin{tabular}{|c|c|c|c|c|c|c|c|}
\hline \multirow[t]{2}{*}{ Tr. No. } & \multirow[t]{2}{*}{ Treatment details } & \multicolumn{2}{|c|}{30 DAP } & \multicolumn{2}{|c|}{45 DAP } & \multicolumn{2}{|c|}{60 DAP } \\
\hline & & $\begin{array}{l}* \text { Per cent } \\
\text { wilt inci- } \\
\text { dence }\end{array}$ & $\begin{array}{l}\text { Per cent re- } \\
\text { duction over } \\
\text { control }\end{array}$ & $\begin{array}{l}* \text { Per cent } \\
\text { wilt inci- } \\
\text { dence }\end{array}$ & $\begin{array}{l}\text { Per cent } \\
\text { reduc- } \\
\text { tion over } \\
\text { control }\end{array}$ & $\begin{array}{l}* \text { Per cent } \\
\text { wilt inci- } \\
\text { dence }\end{array}$ & $\begin{array}{c}\text { Per cent } \\
\text { reduc- } \\
\text { tion over } \\
\text { control }\end{array}$ \\
\hline $\mathrm{T}_{1}$ & Ayurvedic compost ( Full basal) & 2.77 & 77.82 & $\begin{array}{c}13.88^{\mathrm{bc}} \\
(3.73)\end{array}$ & 61.52 & $16.66^{\text {cd }}(3.94)$ & 60.02 \\
\hline $\mathrm{T}_{2}$ & Ayurvedic compost (Two splits ) & 1.38 & 88.95 & $06.94^{\text {bc }}(2.70)$ & 80.77 & $13.88^{\mathrm{cd}}(3.73)$ & 66.69 \\
\hline $\mathrm{T}_{3}$ & Coir pith compost ( Full basal) & 1.38 & 88.95 & $12.49^{\mathrm{bc}}(3.57)$ & 65.40 & $16.66^{\mathrm{cd}}(3.94)$ & 60.02 \\
\hline $\mathrm{T}_{4}$ & Coir pith compost (Two splits ) & 2.77 & 77.82 & $19.44^{\mathrm{ab}}(4.40)$ & 46.14 & $22.22^{\mathrm{bc}}(4.76)$ & 46.68 \\
\hline $\mathrm{T}_{5}$ & Leaf litter compost ( Full basal) & 5.55 & 55.56 & $13.88^{\mathrm{bc}}(3.64)$ & 22.22 & $15.27^{\mathrm{cd}}(3.91)$ & 63.36 \\
\hline $\mathrm{T}_{6}$ & Leaf litter compost (Two splits ) & 1.38 & 88.95 & $16.66^{\mathrm{ab}}(4.07)$ & 50.00 & $18.05^{\mathrm{cd}}(3.94)$ & 56.69 \\
\hline $\mathrm{T}_{7}$ & Mixture compost ( Full basal) & 1.38 & 88.95 & $19.44^{\mathrm{ab}}(4.42)$ & 46.14 & $23.61^{\mathrm{bc}}(4.90)$ & 43.35 \\
\hline $\mathrm{T}_{8}$ & Mixture compost (Two splits ) & 4.16 & 66.69 & $\begin{array}{c}13.88^{\mathrm{bc}} \\
(3.73)\end{array}$ & 61.52 & $24.99^{\mathrm{bc}}(5.03)$ & 40.04 \\
\hline $\mathrm{T}_{9}$ & Aerobic compost ( Full basal) & 6.94 & 44.43 & $16.66^{\mathrm{bc}}(3.91)$ & 53.85 & $23.60^{\mathrm{bc}}(4.88)$ & 43.37 \\
\hline $\mathrm{T}_{10}$ & Aerobic compost (Two splits) & 2.77 & 77.82 & $16.66^{\mathrm{ab}}(4.12)$ & 53.85 & $29.16^{\mathrm{ab}}(5.42)$ & 30.01 \\
\hline $\mathrm{T}_{11}$ & Cow dung@25t/ha (Full basal) & 2.77 & 77.82 & $20.83^{\mathrm{ab}}(4.60)$ & 42.29 & $22.22^{\mathrm{bc}}(4.76)$ & 46.68 \\
\hline $\mathrm{T}_{12}$ & Cowdung@25t/ha (Two splits ) & 2.77 & 77.82 & $18.05^{\mathrm{ab}}(4.18)$ & 50.00 & $30.55^{\mathrm{ab}}(5.55)$ & 26.70 \\
\hline $\mathrm{T}_{13}$ & Copper hydroxide $-2 \mathrm{~g} / \mathrm{l}$ & 0.00 & 100.00 & $04.16^{c}(1.94)$ & 92.35 & $06.93^{\mathrm{d}}(2.97)$ & 86.70 \\
\hline $\mathrm{T}_{14}$ & NPK as per POP & 0.00 & 100.00 & $18.05^{\mathrm{ab}}(4.26)$ & 50.00 & $23.61^{\mathrm{bc}}(4.90)$ & 43.35 \\
\hline $\mathrm{T}_{15}$ & Absolute control & 12.49 & - & $36.10^{\mathrm{a}}(6.06)$ & - & $41.68^{\mathrm{a}}(6.48)$ & \\
\hline $\mathrm{CD}(P=0.05)$ & & - & & 01.65 & & & 01.25 \\
\hline
\end{tabular}

* Mean of three replications DAP - Days after planting DAP - Days after planting * Mean of three replications

Figures in parenthesis are $\sqrt{ } \mathrm{x}+0.5$ transformed values

Figures followed by same letter do not differ significantly according to DMRT

Table 2. Effect of various composts on biometric characters of tomato

\begin{tabular}{|c|c|c|c|c|c|}
\hline \multirow[t]{2}{*}{ Treatments } & \multirow[t]{2}{*}{ Treatment details } & \multicolumn{2}{|c|}{ * Plant height $(\mathrm{cm})$} & \multirow{2}{*}{$\begin{array}{l}\text { * Days to flow- } \\
\text { ering (DAP) }\end{array}$} & \multirow{2}{*}{$\begin{array}{l}* \text { Days to first } \\
\text { harvest (DAP) }\end{array}$} \\
\hline & & 30 DAP & 60 DAP & & \\
\hline $\mathrm{T}_{1}$ & Ayurvedic compost ( Full basal) & $30.25^{\mathrm{cd}}$ & $46.64^{\mathrm{abcd}}$ & 46.13 & 65.33 \\
\hline $\mathrm{T}_{2}$ & Ayurvedic compost (Two splits ) & $37.74^{\mathrm{abc}}$ & $52.02^{\mathrm{abc}}$ & 43.66 & 66.00 \\
\hline $\mathrm{T}_{3}$ & Coir pith compost ( Full basal) & $35.83^{\mathrm{abc}}$ & $41.16^{\text {cde }}$ & 46.00 & 73.00 \\
\hline $\mathrm{T}_{4}$ & Coir pith compost (Two splits ) & $26.33^{\mathrm{d}}$ & $39.44^{\mathrm{de}}$ & 49.00 & 73.66 \\
\hline $\mathrm{T}_{5}$ & Leaf litter compost ( Full basal) & $31.00^{\mathrm{bcd}}$ & $41.60^{\text {bcde }}$ & 47.00 & 73.66 \\
\hline $\mathrm{T}_{6}$ & Leaf litter compost (Two splits ) & $30.75^{\mathrm{cd}}$ & $39.08^{\mathrm{de}}$ & 46.66 & 68.66 \\
\hline $\mathrm{T}_{7}$ & Mixture compost ( Full basal) & $40.25^{\mathrm{ab}}$ & $43.08^{\text {bcde }}$ & 45.66 & 68.66 \\
\hline $\mathrm{T}_{8}$ & Mixture compost (Two splits ) & $31.73^{\mathrm{bcd}}$ & $44.46^{\text {abcde }}$ & 44.00 & 76.00 \\
\hline $\mathrm{T}_{9}$ & Aerobic compost ( Full basal) & $42.74^{\mathrm{a}}$ & $47.97^{\mathrm{abcd}}$ & 45.66 & 70.00 \\
\hline $\mathrm{T}_{10}$ & Aerobic compost (Two splits ) & $39.50^{\mathrm{abc}}$ & $51.50^{\mathrm{abc}}$ & 44.00 & 66.00 \\
\hline $\mathrm{T}_{11}$ & Cow dung@50t/ha ( Full basal) & $44.42^{\mathrm{a}}$ & $53.25^{\mathrm{ab}}$ & 43.66 & 66.00 \\
\hline $\mathrm{T}_{12}$ & Cow dung@50t/ha (Two splits ) & $36.96^{\mathrm{abc}}$ & $46.26^{\mathrm{abcd}}$ & 47.00 & 69.00 \\
\hline $\mathrm{T}_{13}$ & Copper hydroxide $(2 g / 1)+$ NPK & $38.58^{\mathrm{abc}}$ & $57.97^{\mathrm{ab}}$ & 46.33 & 70.00 \\
\hline $\mathrm{T}_{14}$ & NPK as per POP & $43.58^{\mathrm{a}}$ & $59.96^{\mathrm{a}}$ & 44.66 & 66.66 \\
\hline $\mathrm{T}_{15}$ & Absolute control & $23.58^{\mathrm{d}}$ & $34.47^{\mathrm{f}}$ & 51.66 & 73.66 \\
\hline $\mathrm{CD}(P=0.05)$ & & 07.90 & 10.46 & - & - \\
\hline
\end{tabular}

* Mean of three replications

Figures followed by same letter do not differ significantly according to DMRT 
Table 3. Effect of various composts on yield parameters of tomato

\begin{tabular}{|c|c|c|c|c|c|}
\hline Treatments & Treatment details & $\begin{array}{c}* \text { Average number } \\
\text { of fruits/plant }\end{array}$ & $\begin{array}{c}* \text { Average weight } \\
\text { of fruit }(\mathrm{g})\end{array}$ & * Yield/ plant (g) & $\begin{array}{l}* \text { Yield } / 6.48 \\
\mathrm{M}^{2} \text { plot }(\mathrm{kg})\end{array}$ \\
\hline $\mathrm{T}_{1}$ & Ayurvedic compost ( Full basal) & $16.33^{\mathrm{abc}}$ & $29.21^{\mathrm{bc}}$ & $597.39^{\text {abcde }}$ & $08.90^{\mathrm{b}}$ \\
\hline $\mathrm{T}_{2}$ & Ayurvedic compost (Two splits ) & $16.92^{\mathrm{abc}}$ & $40.36^{\mathrm{a}}$ & $626.90^{\mathrm{abcd}}$ & $08.90^{\mathrm{b}}$ \\
\hline $\mathrm{T}_{3}$ & Coir pith compost ( Full basal) & $15.29^{\mathrm{bc}}$ & $27.71^{\mathrm{bc}}$ & $582.60^{\text {abcde }}$ & $05.53^{\text {def }}$ \\
\hline $\mathrm{T}_{4}$ & Coir pith compost (Two splits ) & $13.92^{\mathrm{bc}}$ & $28.53^{\mathrm{bc}}$ & $373.98^{\mathrm{de}}$ & $04.27^{\mathrm{f}}$ \\
\hline $\mathrm{T}_{5}$ & Leaf litter compost ( Full basal) & $14.49^{\mathrm{bc}}$ & $34.12^{\mathrm{ab}}$ & $482.55^{\text {bcde }}$ & $06.56^{\text {cde }}$ \\
\hline $\mathrm{T}_{6}$ & Leaf litter compost (Two splits ) & $15.00^{\mathrm{bc}}$ & $29.38^{c}$ & $419.23^{\text {cde }}$ & $06.30^{\text {cde }}$ \\
\hline $\mathrm{T}_{7}$ & Mixture compost ( Full basal) & $16.75^{\mathrm{abc}}$ & $31.65^{\mathrm{abc}}$ & $499.83^{\text {bcde }}$ & $07.50^{\text {bcd }}$ \\
\hline $\mathrm{T}_{8}$ & Mixture compost (Two splits ) & $18.58^{\mathrm{ab}}$ & $31.00^{\mathrm{bc}}$ & $676.36^{\mathrm{abc}}$ & $08.57^{\mathrm{b}}$ \\
\hline $\mathrm{T}_{9}$ & Aerobic compost ( Full basal) & $18.49^{\mathrm{ab}}$ & $29.25^{\mathrm{bc}}$ & $513.19^{\text {bcde }}$ & $07.90^{\mathrm{bc}}$ \\
\hline $\mathrm{T}_{10}$ & Aerobic compost (Two splits ) & $14.00^{\mathrm{bc}}$ & $25.91^{\mathrm{bc}}$ & $505.80^{\text {bcde }}$ & $05.50^{\text {def }}$ \\
\hline $\mathrm{T}_{11}$ & Cow dung@25t/ha ( Full basal) & $16.92^{\mathrm{abc}}$ & $40.15^{\mathrm{a}}$ & $574.24^{\mathrm{abcde}}$ & $07.20^{\text {bcd }}$ \\
\hline $\mathrm{T}_{12}$ & Cow dung@25t/ha (Two splits ) & $14.67^{\mathrm{bc}}$ & $30.35^{\mathrm{bc}}$ & $484.94^{\text {bcde }}$ & $06.50^{\text {cde }}$ \\
\hline $\mathrm{T}_{13}$ & Copper hydroxide@0.2g/1+NPK & $19.97^{\mathrm{a}}$ & $34.15^{\mathrm{ab}}$ & $799.34^{\mathrm{a}}$ & $12.40^{\mathrm{a}}$ \\
\hline $\mathrm{T}_{14}$ & NPK as per POP & $20.82^{\mathrm{a}}$ & $30.03^{\mathrm{bc}}$ & $741.57^{\mathrm{ab}}$ & $10.90^{\mathrm{a}}$ \\
\hline $\mathrm{T}_{15}$ & Absolute control & $13.00^{\mathrm{c}}$ & $25.22^{\mathrm{bc}}$ & $331.86^{\mathrm{e}}$ & $04.80^{\text {ef }}$ \\
\hline $\mathrm{CD}(P=0.05)$ & & 06.06 & 08.23 & 242.10 & 01.78 \\
\hline
\end{tabular}

* Mean of three replications

Figures followed by same letter do not differ significantly according to DMRT

were maximum with NPK application with soil drenching of copper hydroxide $\left(\mathrm{T}_{13}\right)$ followed by $10.9 \mathrm{~kg} / 6.48 \mathrm{~m}^{2}$ in NPK application alone $\left(\mathrm{T}_{14}\right)$. Among the different composts, split and basal application of ayurvedic compost $\left(\mathrm{T}_{2}\right.$ and $\mathrm{T}_{1}$ ) recorded highest yield of $8.9 \mathrm{~kg} / 6.48 \mathrm{~m}^{2}$ which was on par with split application of mixture compost, $\mathrm{T}_{8}$ $\left(8.6 \mathrm{~kg} / 6.48 \mathrm{~m}^{2}\right)$.

Use of agricultural chemicals is the most widely used strategy for controlling pest and diseases. Chemical control measures are not generally preferred in the modern world owing to their health risks and environmental impact. So there is considerable interest in manipulating soil environment to achieve biocontrol of important soil borne pathogens. Moreover, the current trend of zero market tolerance for pesticide residues in agricultural produce resulted in the search of alternate safe strategies in disease control. During recent years application of bioagents as well as soil amendments are found to be effective methods in combating plant diseases. Composts have been used for centuries to maintain soil fertility and crop health and considerable research have been conducted on the disease suppression by compost products (Hoitink and Fahy, 1986; Schuler et al., 1983). The disease suppression is mainly due to the direct interactions between antagonistic microorganisms in the composts and the pathogens by the way of competition, antibiosis or hyperparasitism (Hoitink et al., 1993) and also due to the indirect action by the activation of induced systemic resistance or by the enhancement of plant growth (Zhang et al., 1996; Sang et al., 2010 and Yogev et al., 2010).

Considering the overall performances of various treatments, lignin-tannin rich compost products were found effective in suppressing bacterial wilt and ayurvedic compost was found to be the best in disease management and in promoting plant growth characters. This can be correlated with the direct and indirect action of composts products rich in tannins/phenols which might have resulted in disease suppression and subsequent yield enhancement. The inhibitory effect of extracts of medicinal plants on plant pathogens has been reported by many workers. Mathew et al., (2004) observed the inhibitory effect of 10 per cent Adathoda extract on $R$. solanacearum causing bacterial wilt in solanaceous vegetables. However, search on literature has not provided any information regarding the effect of ayurvedic compost products in the suppression of phytopathogens. Perhaps, this may be the first attempt in the management of soil borne diseases with ayurvedic compost.

Bacterial wilt caused by $R$. solanacearum is the major constraint in the production of tomato and the genetic diversity of the pathogen often overcomes the crop resistance (Wang et al., 1998). Furthermore, the use of chemicals has its adverse effects both on environment as well as on ben- 
eficial microorganisms. This study revealed the application of ligno-phenolic composts especially ayurvedic compost has the potential to manage bacterial with enhanced yield parameters. The study also caters two major issues faced by the present day farming community viz. waste as well as disease management. Since the use of composts is ecologically safe, this can be adopted as one of the best environmentally safe disease control strategy against bacterial wilt of tomato.

\section{ACKNOWLEDGEMENT}

The authors are grateful to UGC, Maulana Azad National Fellowship and the Kerala State Council for Science, Technology and Environment for the financial support.

\section{REFERENCES}

Deokar CD, Sawant DM. 2004. Compost cultures and their production. Agric Microbiol. 2: 44-45.

Freed. 1986. MSTAT version 1.2. Department of Crop and Soil Sciences, Michigan State University, 158p.

Hayward AC. 1991. Biology and epidemiology of bacterial wilt caused by Pseudomonas solanacearum. Annu Rev Phytopathol. 29(1): 65-87.

Hoitink HA, Fahy PC. 1986. Basis for the control of soilborne plant pathogens with composts. Annu Rev Phytopathol. 24(1): 93-114.

Hoitink HAJ, Boehm MJ, Hadar Y. 1993. Mechanism of suppression of soil borne plant pathogen in compost-amended substrates, pp. 601-621. In: Keener HA. (Ed.). Science and engineering of composting: Design, environmental, microbiological and utilization aspects. Renaissance Publications, Worthington, Ohio.

Kelman A. 1953. The relationship of pathogenicity of Pseudomonas solanacearum. A literature review and bibliography. North Carolina Agric Expt Sta Tech Bul. 99: 194.
Mathew SK. 2004. Biocontrol of Ralstonia solanacearum E.F. Smith. causing bacterial wilt in solanaceous vegetable crops. ICAR Project Final Report, Kerala Agricultural University, Thrissur, 64p.

Sadhankumar PG. 1995. Incorporation of resistance to fruit cracking in a bacterial wilt resistant genetic background in tomato. Ph.D thesis, Kerala Agricultural University, Thrissur, 151p.

Sang MK, Kim JG, Kim KD. 2010. Biocontrol activity and induction of systemic resistance in pepper by compost water extracts against Phytophthora capsici. Phytopathol. 100(8): 774-783.

Schuler C, Pikny J, Nasir M, Vogtmann H. 1983. Effects of composted organic kitchen and garden waste on Mycosphaerella pinodes (Berk. et Blox) Vestergr., causal organism of foot rot on peas (Pisum sativum) Biolog Agric Hort. 9:353-360.

Thimmaiah SK. 1989. A manual for research methods for analysis of agricultural products. University of Agricultural Sciences, Dharwad, 263p.

Thormann MN, Currah RS, Suzanne EB. 2002. The relative ability of fungi from Sphagnum fuscum to decompose selected carbon sources. Can J Microbiol. 48: 204-211.

Wang JF, Hanson P, Barnes JA. 1998. Worldwide evaluation of an international set of research sources to bacterial wilt in tomato, pp. 269-275. In: Bacterial wilt disease, Springer Link, USA.

Yogev A, Raviv M, Hadar Y, Cohen R, Wolf S, Gil L, Katan J. 2010. Induced resistance as a putative component of compost suppressiveness. Biol Control 54(1): 46-51.

Zhang W, Dick WA, Hoitink HAJ. 1996. Compost induced systemic acquired resistance in cucumber to Pythium root rot and anthracnose. Phytopathol. 86: 1066-1070. 